\title{
Dietary starch source influences in growing goats: the intestinal losses of endogenous nitrogen and amino acids
}

\author{
Chuanshe Zhou ${ }^{1}$, Zhiliang Tan ${ }^{1}$, Yafei Pan $^{1}$, Shimin Liu $^{2}$, Shaoxun Tang ${ }^{1,3}$, Zhihong Sun ${ }^{1,3}$, Xuefeng Han ${ }^{1}$ \\ and Min Wang ${ }^{1}$ \\ ${ }^{1}$ Key Laboratory of Agro-ecological Processes in Subtropical Region, Institute of Subtropical Agriculture, Chinese Academy of \\ Sciences, Changsha 410125, China \\ ${ }^{2}$ The University of Western Australia, Perth 6009, Australia \\ ${ }^{3}$ Graduate University of Chinese Academy of Sciences, Beijing 100039, China
}

(Received 8 July 2009 - Revised 5 January 2010 - Accepted 8 January 2010 - First published online 8 March 2010)

\begin{abstract}
Four goats $(20(\mathrm{SD} 2 \cdot 5) \mathrm{kg}$ ) fitted with ruminal, duodenal and ileal cannulae were used in a $4 \times 4$ Latin square design to estimate the effects of a dietary starch source on the duodenal and ileal flows of endogenous N (EN) and endogenous amino acids (EAA) in growing goats. Goats were fed total mixed rations containing four starch sources (mainly from maize (MR), wheat (WR), paddy (PR) and sorghum (SR) treatments). There were no significant $(P>0.05)$ effects of the dietary starch source on the intestinal flows of EN and EAA. The duodenal flows of EN were $2 \cdot 40,2 \cdot 39,2 \cdot 18$ and $1.56 \mathrm{~g} / \mathrm{d}$ for the MR, WR, PR and SR treatments, respectively, as determined by the difference method, and the duodenal flows of EAA were $10 \cdot 76,11 \cdot 29,10.95$ and $10.96 \mathrm{~g} / \mathrm{d}$ by estimation with the amino acid profile method. The flows of EN and EAA at the ileum were $1 \cdot 17,1 \cdot 12,1 \cdot 01$, 0.70 and $4.87,4.95,4.94,4.99 \mathrm{~g} / \mathrm{d}$, respectively, as estimated by the water-soluble method. The average intestinal reabsorption of EN and EAA was $57.5 \%$, and the endogenous Leu by the MR treatment was significantly $(P<0.05)$ lower than that of the other three treatments. The present results indicate that losses of endogenous protein in the intestine were not affected by the dietary starch source.
\end{abstract}

Starch source: Endogenous nitrogen: Endogenous amino acids: Goats

The determination of the true digestibility of $\mathrm{N}$ and amino acids (AA) in feedstuffs is of great interest for animal production because it allows for better adjustment of the supply to the requirement and reduction of $\mathrm{N}$ pollution ${ }^{(1,2)}$. Correction of the significant losses of endogenous $\mathrm{N}(\mathrm{EN})$ and endogenous amino acids (EAA) occurring during digestion and absorption along the gastrointestinal tract is necessary for estimating the true digestibility of $\mathrm{N}$ and for measuring the $\mathrm{N}$ and AA requirements by factorial methods. The endogenous contribution has not received much attention until recently and the estimates used have been fairly low. Several reports have acknowledged that the endogenous protein makes up a considerable fraction of the duodenal $\mathrm{N}$ flow ${ }^{(3-5)}$. However, it is difficult to determine the losses of EN and EAA in ruminants because their $\mathrm{N}$ and AA supplies originate from both micro-organisms and ruminally undegraded feed protein. Prediction of the supply from each of these origins has to be based on experiments with ruminants cannulated at the start of the small intestine, and the total flows of $\mathrm{N}$ and AA must be separated with respect to the origin. This separation is complicated by the endogenous secretion of $\mathrm{N}$ and AA during digestion originating predominantly from various digestive secretions, mucoproteins, and desquamated epithelial cells shed from the gut lining and the intestinal flora ${ }^{(6,7)}$.

Secretion and/or reabsorption of EN and EAA are influenced by many factors, including animal species ${ }^{(6)}$, body weight $^{(8)}$, DM intake $(\mathrm{DMI})^{(6,8)}$, dietary protein content and quality $^{(3)}$ and dietary fibre content ${ }^{(6,9)}$. Starch usually supplies energy and is an important component of the animal diet, with cereal grains serving as the primary source of starch in ruminant diets. Maize, wheat, rice and sorghum are commonly used worldwide as a starch source in all animal feeds, including ruminants ${ }^{(10)}$. Grain texture plays a major role in the rate and location of starch digestion in ruminants ${ }^{(11)}$, and variations in the starch granule structure among species of cereal grains may account for distinct rates of digestion patterns ${ }^{(12)}$. In a previous study, we demonstrated that the dietary starch source had significant effects on the ruminal degradation and intestinal digestion in goats ${ }^{(13,14)}$. Our hypothesis was that these variations influenced the losses of EN and EAA in ruminants. The AA composition of the endogenous protein at different sites of the digestive tract has received little attention in growing goats, and accurate determination of EN and EAA along the digestive tract is essential for

Abbreviations: AA, amino acid; AAP, amino acid profile; DAPA, diaminopimelic acid; DMI, dry matter intake; EAA, endogenous amino acid; EN, endogenous N; $\mathrm{NDF}$, neutral-detergent fibre; TEAA, total essential amino acid; TN, total N.

* Corresponding author: Dr Zhiliang Tan, fax +86731 4612685, email zltan@isa.ac.cn 
optimising protein nutrition in ruminants. Therefore, the objective of the present study was to investigate the effects of the dietary starch source on EN and EAA losses along the gastrointestinal tract in growing goats.

\section{Materials and methods}

\section{Animals and management}

The experiment was conducted according to the animal care and use guidelines of the Animal Care Committee, Institute of Subtropical Agriculture, Chinese Academy of Sciences, Changsha, China.

Four Liuyang black growing wethers (a local breed in the South of China) with initial body weights of 20 (SD 2.5$) \mathrm{kg}$ were each fitted with a ruminal plastic cannula $(4 \mathrm{~cm}$ internal diameter) and proximal duodenal and terminal ileal fistulae (T-type, $1 \mathrm{~cm}$ internal diameter; Laboratory Factory, Yinchuan, Ninxia University). The animals were kept individually in stainless-steel metabolism cages in a temperature-controlled $\left(21^{\circ} \mathrm{C}\right)$ and constantly lit animal house with free access to fresh water.

\section{Experimental diets and design}

The experiment was carried out in a $4 \times 4$ Latin square design, with four goats, four dietary treatments (the dietary starch sources were mainly from maize, wheat, paddy and sorghum) and four periods. The formal experiment for each period lasted for $24 \mathrm{~d}$, consisting of $14 \mathrm{~d}$ for adaptation, $3 \mathrm{~d}$ for in situ degradability of dietary protein determination and $7 \mathrm{~d}$ for sample collection.

The ingredients and chemical composition of the experimental total mixed rations are shown in Table 1 . The total mixed rations were offered and the refusals were collected and weighed daily for $7 \mathrm{~d}$ before the commencement of the formal experiment to measure the voluntary feed intake. During the formal experiment, the supplied experimental total mixed rations were fed in equal portions at 07.00 and 19.00 hours daily to meet 1.3 times the maintenance requirements of the metabolisable energy according to the nutrient requirements of Chinese goats ${ }^{(15)}$. To avoid feed refusals, the amount of the diets offered to each goat was controlled at $90 \%$ of its voluntary feed intake measured before the commencement of the experiment.

\section{In situ protein degradation}

The in situ degradability of the dietary protein was examined from day 15 to day 17 according to the modified procedure of Tan et al. ${ }^{(16)}$. The passage rate $\left(\mathrm{K}_{\mathrm{p}}\right)$ was calculated according to the following equation described by the National Research Council ${ }^{(5)}: \mathrm{K}_{\mathrm{p}}(\% / \mathrm{h})=3.362+0.479 \times(\mathrm{DMI}, \%$ of body weight $)-0.017 \times(\%$ neutral-detergent fibre (NDF), DM basis $)-0.007 \times(\%$ concentrate in diet, DM basis $)$. The calculated average $\mathrm{K}_{\mathrm{p}}$ value was $0.051 \% / \mathrm{h}$ in the present study. The effective rumen degradability of the dietary protein was calculated by the equation of Øskov \& McDonald ${ }^{(17)}$. The dietary rumen degraded protein was calculated by multiplying the effective rumen degradability by the dietary $\mathrm{N}$ or AA content, and the rumen undegraded protein was determined
Table 1. Ingredients and chemical composition of the experimental diets (\% DM)

\begin{tabular}{|c|c|c|c|c|}
\hline \multirow[b]{2}{*}{ Dietary starch source... } & \multicolumn{4}{|c|}{ Diets } \\
\hline & Maize & Wheat & Paddy & Sorghum \\
\hline \multicolumn{5}{|l|}{ Ingredients (\% diet) } \\
\hline Maize stover & 60.00 & $60 \cdot 00$ & 60.00 & $60 \cdot 00$ \\
\hline Maize & $25 \cdot 27$ & - & - & - \\
\hline Wheat & - & $25 \cdot 19$ & - & - \\
\hline Paddy & - & - & 28.73 & - \\
\hline Sorghum & - & - & - & $25 \cdot 62$ \\
\hline Soyabean meal & 6.83 & 5.92 & 2.48 & 5.47 \\
\hline Paddy hull & 2.35 & $3 \cdot 27$ & $2 \cdot 84$ & $3 \cdot 15$ \\
\hline Fish meal & 3.75 & 3.82 & $4 \cdot 15$ & 3.96 \\
\hline Sodium chloride & 0.80 & 0.80 & 0.80 & 0.80 \\
\hline Premix ${ }^{\star}$ & 1.00 & 1.00 & 1.00 & 1.00 \\
\hline \multicolumn{5}{|l|}{ Chemical composition } \\
\hline $\begin{array}{l}\text { Metabolisable energy } \\
(\mathrm{kJ} / \mathrm{kg} \mathrm{DM}) \dagger\end{array}$ & 10157 & 9823 & 9739 & 9823 \\
\hline Crude protein (\% DM) & $13 \cdot 13$ & $12 \cdot 76$ & 12.52 & $12 \cdot 67$ \\
\hline $\begin{array}{l}\text { Neutral-detergent fibre } \\
(\% \text { DM) }\end{array}$ & 39.62 & $40 \cdot 77$ & $40 \cdot 30$ & $40 \cdot 93$ \\
\hline Starch (\% DM) & $25 \cdot 61$ & 24.89 & $24 \cdot 64$ & 24.98 \\
\hline Ca (\% DM) & 0.64 & 0.58 & 0.58 & 0.74 \\
\hline$P(\% D M)$ & 0.24 & 0.24 & 0.41 & 0.31 \\
\hline
\end{tabular}

by subtracting the rumen degraded protein from the dietary protein content.

\section{Sample collection}

Feed samples were taken before feeding. From day 18 to day 24 of each period, a total of $4 \mathrm{~g}$ of chromic oxide $\left(\mathrm{Cr}_{2} \mathrm{O}_{3} ; 1 \mathrm{~g}\right.$ every $6 \mathrm{~h}$ per $\mathrm{d}$ ), as the particulate-phase digesta marker, was administered daily via the rumen fistulae at 06.00, $12.00,18.00$ and 24.00 hours $^{(16)}$. Samples $(50 \mathrm{ml}$ of ruminal, $50 \mathrm{ml}$ of duodenal and $30 \mathrm{ml}$ of ileal digesta) were collected at $05.00,11.00,17.00$ and 23.00 hours on day 22, at 03.00, 09.00, 15.00 and 21.00 hours on day 23 and at 01.00, 07.00, 13.00 and 19.00 hours on day 24. At the end of each period, equal portions of the ruminal, duodenal and ileal samples were pooled. The pooled ruminal digesta were collected to isolate bacteria, and the pooled duodenal and ileal digesta were collected to measure the digesta flows. The ileal samples were chilled to $5^{\circ} \mathrm{C}$ until all twelve samples were collected in order to avoid lysis of bacteria, which would introduce cellular content into the water-soluble phase. From day 18 to day 21, the total faeces and urine were collected and subsampled for analyses for the determination of the $\mathrm{N}$ balance.

\section{Sample handling}

The pooled ruminal digesta were used to isolate bacteria by differential centrifugation according to the procedure of Reed et al. ${ }^{(18)}$. The isolated bacteria were freeze-dried (GLZY-0.5B; Pudong Freeze Dryer Equipment Co., Ltd, Shanghai, China), and then mashed with a mortar and pestle for analysis of microbial DM, N and AA (including 
diaminopimelic acid (DAPA)). The pooled duodenal and ileal digesta were separated as follows: one subsample of the duodenal and ileal digesta was freeze-dried and further analysed for $\mathrm{DM}, \mathrm{Cr}, \mathrm{N}$ and $\mathrm{AA}$, respectively. The other subsample of duodenal digesta was used to isolate bacteria by differential centrifugation according to the procedure of Reed et al. ${ }^{(18)}$, and the isolated bacteria were used to analyse the microbial DM, $\mathrm{N}$ and AA (including DAPA). A subsample (100 g) of the pooled ileal digesta was added to $100 \mathrm{~g}$ of demineralised water and then shaken for $5 \mathrm{~min}$, and the resulting suspension was squeezed through two layers of cheesecloth. The remaining feed particles and protozoa were removed by centrifugation $\left(409 \mathrm{~g} ; 5 \mathrm{~min} ; 3^{\circ} \mathrm{C}\right)$, and the bacterial fraction in the ileal digesta was removed by centrifuging the supernatant fraction twice $\left(17300 \mathrm{~g} ; 20 \mathrm{~min} ; 3^{\circ} \mathrm{C}\right)$. The supernatant fraction was frozen for the analysis of water-soluble $\mathrm{N}$ and $\mathrm{AA}^{(19)}$. A $50 \mathrm{~g}$ representative sample of each daily faeces was frozen at $-20^{\circ} \mathrm{C}$ for later analyses. The urine was acidified daily with $50 \mathrm{ml}$ of $0.75 \mathrm{M}-\mathrm{H}_{2} \mathrm{SO}_{4}$ during its collection. Subsamples of urine were taken daily and kept at $-20^{\circ} \mathrm{C}$ until analysis.

\section{Chemical analyses}

The DM content of the feed, remaining feed (orts), faeces, digesta, incubated nylon bag samples and freeze-dried bacteria was determined by drying at $65^{\circ} \mathrm{C}$ to a constant weight. The faeces, feed, orts and digesta were ground through a $0.5 \mathrm{~mm}$ screen with a laboratory mill (DF-2; Changsha Instrument Factory, Changsha City, China). The total $\mathrm{N}$ content of the feed, orts, faeces, urine, digesta and incubated nylon bag samples was analysed according to AOAC methods ${ }^{(20)}$ and that of bacteria was determined by the Dumas method according to Hansen ${ }^{(21)}$. The AA content, including DAPA, was determined according to Mason et al. ${ }^{(22)}$. Chromic oxide analysis on digesta was determined colorimetrically after oxidation to chromate according to Schurch et al. ${ }^{(23)}$.

\section{Calculations}

The flows of DM, N and AA at the duodenum and ileum were calculated as described by Sun et al. ${ }^{(24)}$. The duodenal flows of microbial $\mathrm{N}$ and $\mathrm{AA}$ were determined by the internal microbial marker $\mathrm{DAPA}^{(25)}$, and the microbial passage at the duodenum was calculated from the concentration of DAPA in isolated rumen bacteria and the passage of DAPA at the duodenum. The following equations were used to calculate the duodenal flows of microbial $\mathrm{N}$ and $\mathrm{AA}^{(26)}$ :

$$
\begin{gathered}
\mathrm{R}=\frac{D P d / N d}{D P m / N m}, \\
\mathrm{Mp}=\mathrm{R} \times \mathrm{DFN},
\end{gathered}
$$

where $\mathrm{R}$ indicates the ratio of microbial $\mathrm{N}$ to total $\mathrm{N}$ or AA of digesta, $\mathrm{DP}_{\mathrm{d}}$ and $\mathrm{N}_{\mathrm{d}}$ stand for the concentration of DAPA and $\mathrm{N}$ in the digesta, respectively, $\mathrm{DP}_{\mathrm{m}}$ and $\mathrm{N}_{\mathrm{m}}$ are the concentrations of DAPA and $\mathrm{N}$ in isolated rumen bacteria, $\mathrm{Mp}$ is the flow of microbial $\mathrm{N}$ at the duodenum, and DFN stands for the flow of $\mathrm{N}$ in the digesta at the duodenum.
The calculated equation for the duodenal flows of EN or EAA is:

$$
\begin{aligned}
\text { Endogenous flow }= & \text { total flow }- \text { microbial flow } \\
& - \text { undegraded feed flow. }
\end{aligned}
$$

The duodenal flow of $\mathrm{N}$ and individual AA was also separated by origin by the amino acid profile (AAP) method ${ }^{(2,3,27,28)}$. This mathematical method estimates the contribution of total $\mathrm{N}$ and $\mathrm{AA}$ from each origin by solving the following equation using the least squares calculation with SAS procedure PROC REG (SAS Institute, Inc., Cary, NC, USA) ${ }^{(29)}$ :

$$
\begin{aligned}
\mathrm{AA}_{i}= & \beta_{1} \times \text { FeedAA }_{i}+\beta_{2} \times \text { MicAA }_{i}+\beta_{3} \times \text { AboAA }_{i} \\
& +\beta_{4} \times \text { BileAA }_{i},
\end{aligned}
$$

where $\mathrm{AA}_{\mathrm{i}}$ is the $i$ th $\mathrm{AA}$ flow in the duodenum; $i$ is the individual $\mathrm{AA}(i=1-16) ; \beta_{1-4}$ is total $\mathrm{AA}$ from each origin; FeedAA $A_{i}, \operatorname{MicAA}_{\mathrm{i}}, \mathrm{AboAA}_{\mathrm{i}}$ and $\mathrm{BileAA}_{\mathrm{i}}$ are the $i$ th AA proportion in undegraded protein in total mixed rations, microbial protein, and endogenous protein in abomasum and bile, respectively. The AA profiles of abomasal fluid and bile were previously determined in our laboratory using twenty-three slaughtered goats.

The ileal EN and EAA were assumed to be located in the water-soluble phase and the apparent reabsorption of EN and EAA was calculated according to the method of Larsen et al. ${ }^{(19)}$.

\section{Statistical analyses}

The results were analysed using the SAS procedure PROC GLM (SAS Institute, Inc.) ${ }^{(29)}$ with the following model:

$$
\mathrm{Y}_{\mathrm{ijk}}=\mu+\text { Period }_{\mathrm{i}}+\text { Goat }_{\mathrm{j}}+\text { Treatment }_{\mathrm{k}}+\epsilon_{\mathrm{ijk}},
$$

where $Y_{i j k}$ is the response, $\mu$ is the overall mean, Period $d_{i}$ is the effect of the period ( $i=1-3$ ), Goat ${ }_{j}$ is the effect of the goat $(j=1-3)$, and Treatment $t_{k}$ is the effect of the dietary starch source treatment $(\mathrm{k}=1-3)$. The error $\left(\epsilon_{\mathrm{ijk}}\right)$ was assumed to be independent and $\mathrm{N}\left(0, \sigma^{2}\right)$. Statistical effects were considered to be significant when the probabilities $(P)$ were below $0 \cdot 05$, and tendencies were considered at $0 \cdot 05<P<0 \cdot 10$.

\section{Results}

The duodenal flow, ileal flow and intestinal reabsorption of EN are presented in Table 2. There were no significant differences $(P>0.05)$ for $\mathrm{N}$ intake, duodenal flow of total $\mathrm{N}$ (TN), undegraded feed $\mathrm{N}$, microbial $\mathrm{N}(\mathrm{MN}), \mathrm{EN}$, ileal flow or intestinal absorption of EN. The average ratio of MN:TN at the duodenum was from $56.0 \%$ (maize) to $63.8 \%$ (sorghum), and the average absorption of $\mathrm{EN}$ in the intestine was about $53.1 \%$.

Table 3 presents the effects of the dietary starch source on the duodenal flow, ileal flow and intestinal reabsorption of EAA. There were no significant differences $(P>0.05)$ in the duodenal or ileal flow of EAA among treatments. The dietary starch sources had no effect on the intestinal reabsorption of EAA, except for Leu. The intestinal reabsorption of endogenous Leu was significantly $(P<0.05)$ lower for the maize 
Table 2. Effect of starch source on the duodenal flow, ileal flow and intestinal reabsorption of endogenous nitrogen $(E N)$ in growing goats $(\mathrm{g} / \mathrm{d})$ (Mean values with their pooled standard errors)

\begin{tabular}{|c|c|c|c|c|c|c|}
\hline \multirow[b]{2}{*}{ Item } & \multicolumn{4}{|c|}{ Treatments } & \multirow[b]{2}{*}{ SEM } & \multirow[b]{2}{*}{$P$} \\
\hline & Maize & Wheat & Paddy & Sorghum & & \\
\hline$N$ intake $^{*}$ & 11.67 & $12 \cdot 86$ & $10 \cdot 91$ & 11.95 & 0.99 & 0.61 \\
\hline \multicolumn{7}{|l|}{ Duodenal flow } \\
\hline Total N & $12 \cdot 61$ & 13.77 & 11.77 & $12 \cdot 67$ & $1 \cdot 28$ & 0.63 \\
\hline Microbial N & 7.06 & 7.94 & 6.90 & 8.08 & 0.63 & 0.43 \\
\hline $\begin{array}{l}\text { Undegraded } \\
\text { feed N }\end{array}$ & 3.14 & 3.44 & $2 \cdot 69$ & 3.03 & 0.15 & 0.37 \\
\hline EN & $2 \cdot 40$ & 2.39 & $2 \cdot 18$ & 1.56 & 0.12 & 0.31 \\
\hline Ileal EN flow & $1 \cdot 17$ & $1 \cdot 12$ & 1.01 & $0 \cdot 70$ & 0.15 & 0.21 \\
\hline $\begin{array}{l}\text { Intestinal } \\
\text { reabsorption } \\
\text { of EN }\end{array}$ & $51 \cdot 0$ & $53 \cdot 3$ & $53 \cdot 2$ & $54 \cdot 8$ & $1 \cdot 38$ & 0.36 \\
\hline
\end{tabular}

* Intake measured during the total collection period.

treatment than for the other three treatments. The average reabsorption of endogenous protein was $57.5 \%$.

\section{Discussion}

\section{Effects of dietary starch source}

Over the last few years, several studies have been conducted to test the effects of dietary factors on the loss of EN and EAA along the gastrointestinal tract on the DM intake ${ }^{(30,31)}$, fibre content ${ }^{(2,6,32)}$, protein quantity and quality ${ }^{(33)}$ and antinutritive factors ${ }^{(34-36)}$ in both ruminants and single-stomached animals. Some studies have been conducted to examine the influence of the dietary starch source on feed consumption, ruminal fermentation parameters, skeletal growth, blood metabolites, nutrient digestion, and growth performance in ruminants $^{(37-41)}$. To our knowledge, few studies have been conducted to evaluate the effects of dietary starch sources on the flows of EN and EAA in ruminants. The results of the present study indicated that there are no effects of dietary starch source on the intestinal flows of EN and EAA in growing goats. The chemical components with unique physical properties of dietary starch, its relationship to proteins, and the cellular integrity of starch-containing units affect the availability to microbes, nutrient digestibility ${ }^{(42)}$ and produce energy in the intestine ${ }^{(43)}$, which may result in the variations of EN losses and EAA composition. Further studies are needed to investigate the effects of dietary starch levels and the ratios of starch: $\mathrm{N}$ on losses of endogenous materials along the gastrointestinal tract in ruminants.

\section{Duodenal flows of endogenous nitrogen and endogenous amino acids}

In the present study, $\mathrm{Cr}_{2} \mathrm{O}_{3}$ was selected as the particulate phase digesta marker. Within the last few years, considerable attention has been given to indicator methods for determining digestibility. The new methods are advantageous for saving time, labour and equipment. Hamilton et al. ${ }^{(44)}$ used $\mathrm{Cr}_{2} \mathrm{O}_{3}$ to study estimated coefficients of digestibility and found that the length of the sampling period should be $\geq 3 \mathrm{~d}$ to reduce sampling errors. Crampton \& Lloyd ${ }^{(45)}$ concluded that $\mathrm{Cr}_{2} \mathrm{O}_{3}$ recovery was 98 to $99 \%$ when sheep received a hay plus grain ration, even $3 \mathrm{~d}$ after $\mathrm{Cr}_{2} \mathrm{O}_{3}$ administration had stopped. To confirm the stable marker concentrations in the rumen and intestine, the goats were fed with total mixed rations and the $\mathrm{Cr}_{2} \mathrm{O}_{3}$ administration was continued for $7 \mathrm{~d}$ in the present study. Estimates of the flows of endogenous protein in the duodenum vary from $16 \%$ of the total protein flow ${ }^{(46)}$ to $56 \%{ }^{(47)}$. Van Bruchem et al. ${ }^{(48)}$ used a continuous abomasal infusion of ${ }^{15} \mathrm{~N}$-labelled, grass meal-beer yeast suspension, and reported that the endogenous contribution accounted for $12 \%$ of the duodenal $\mathrm{N}$ flow in sheep. In addition, Sandek et al. ${ }^{(49)}$ reported that EN contributed to 3-12\% of the duodenal flow of total $\mathrm{N}$ determined by the ${ }^{15} \mathrm{~N}$-labelled method for diets ranging from 15 to $25 \%$ of crude fibre content in sheep. Ouellet et al. ${ }^{(32)}$ found that the average contribution of EN to TN at the duodenum was $14 \%$ when estimated by the ${ }^{15} \mathrm{~N}$ dilution technique in Holstein cows fed high-fibre (containing $37.4 \% \mathrm{NDF}$ ) and low-fibre (containing $23.3 \%$ $\mathrm{NDF}$ ) diets. Using an infusion of $\left[{ }^{15} \mathrm{~N}\right]$ leucine in lactating cows, Lapierre et al. ${ }^{(50)}$ demonstrated that the EN contribution to the duodenal $\mathrm{N}$ flow averaged at $18 \%$ when silage was fed and at $20 \%$ when hay was offered. In the present study, the average endogenous contribution to the duodenal TN flow was $17 \%$, which is within the range of previously published values. Variations between the various reports could be due to differences of cannulae positions, analytical methods, diet compositions and experimental animal species.

Larsen et al. ${ }^{(3)}$ found that the average duodenal flow of EN was $10.0 \mathrm{~g} / \mathrm{kg}$ DMI when estimated by the difference method in lactating cows fed diets low in AA content. Using the AAP method, Larsen et al. ${ }^{(19)}$ reported that the average duodenal flow of total essential amino acids (TEAA) was $25.6 \mathrm{~g} / \mathrm{kg}$ DMI in dairy cows. Ouellet et al. ${ }^{(32)}$ demonstrated that the mean duodenal flow of EN was $4.4 \mathrm{~g} / \mathrm{kg} \mathrm{DMI}$, which was estimated by the ${ }^{15} \mathrm{~N}$ dilution method in Holstein cows fed with diets containing different NDF contents. By contrast, Jensen et al. ${ }^{(51)}$ reported that the duodenal flow of EN was $7.9 \mathrm{~g} / \mathrm{kg}$ DMI using the AAP method in lactating Danish HolsteinFriesian cows fed maize silage. Zhou et al. ${ }^{(2)}$ found that the mean duodenal flows of EN and TEAA were $2 \cdot 1$ and $11.8 \mathrm{~g} / \mathrm{kg}$ DMI by estimation with the difference method and the AAP method in growing goats fed diets containing different NDF levels, respectively. In the present study, the average duodenal flows of EN and TEAA were 3.7 and $19.0 \mathrm{~g} / \mathrm{kg}$ DMI, as determined by the difference and AAP methods, respectively. The differences of EN and TEAA between goats and dairy cows might result from the different computational processes among the determination methods. Furthermore, the big size and relatively large amount of protein turnover for dairy cows might result in greater losses of EN at the duodenum ${ }^{(50)}$, which needs to be further examined in future studies. The flows of EN and TEAA in the present study were higher than those of our previous study ${ }^{(2)}$, probably because of the greater dietary NDF content $(40.4 v .35 .6 \%)$ in the present study, an important factor affecting the endogenous protein losses $^{(6,8,52,53)}$, or the lower level of feed intake (only $1 \cdot 3$ times the maintenance requirement for metabolisable energy). Some studies have shown that endogenous losses are sensitive to feed intake $e^{(30,31,54-56)}$. The losses of EN and EAA (measured in $\mathrm{g} / \mathrm{kg} \mathrm{DMI}$ ) in pigs fed at the maintenance metabolisable energy are twice that if pigs are fed three times 
Table 3. Effect of starch source on the flow of endogenous amino acids at the duodenum and ileum and intestinal reabsorption in growing goats $(\mathrm{g} / \mathrm{d})$

(Mean values with their pooled standard errors)

\begin{tabular}{|c|c|c|c|c|c|c|}
\hline \multirow[b]{2}{*}{ Item } & \multicolumn{4}{|c|}{ Treatments } & \multirow[b]{2}{*}{ SEM } & \multirow[b]{2}{*}{$P$} \\
\hline & Maize & Wheat & Paddy & Sorghum & & \\
\hline \multicolumn{7}{|l|}{ Arg } \\
\hline Duodenum & 0.65 & 0.59 & 0.65 & 0.58 & 0.03 & 0.26 \\
\hline Ileum & 0.23 & 0.21 & 0.24 & 0.20 & 0.02 & 0.29 \\
\hline Reabsorption & 63.8 & $65 \cdot 0$ & $62 \cdot 6$ & $66 \cdot 1$ & 1.83 & 0.60 \\
\hline \multicolumn{7}{|l|}{ His } \\
\hline Duodenum & 0.45 & 0.41 & 0.43 & 0.46 & 0.04 & 0.80 \\
\hline Ileum & $0 \cdot 15$ & 0.15 & 0.14 & 0.15 & 0.02 & 0.99 \\
\hline Reabsorption & $67 \cdot 3$ & 63.6 & $66 \cdot 8$ & $66 \cdot 4$ & 3.53 & 0.88 \\
\hline \multicolumn{7}{|l|}{ Ile } \\
\hline Duodenum & 0.87 & 0.86 & 0.87 & 0.91 & 0.03 & 0.74 \\
\hline Ileum & 0.33 & 0.32 & 0.31 & 0.34 & 0.03 & 0.88 \\
\hline Reabsorption & $62 \cdot 0$ & 62.0 & $64 \cdot 3$ & 62.5 & 2.54 & 0.90 \\
\hline \multicolumn{7}{|l|}{ Leu } \\
\hline Duodenum & 1.02 & 1.15 & 1.03 & 1.08 & 0.05 & 0.36 \\
\hline Ileum & 0.36 & 0.35 & 0.32 & 0.34 & 0.02 & 0.61 \\
\hline Reabsorption & $65 \cdot 0^{\mathrm{b}}$ & $69 \cdot 2^{\mathrm{a}}$ & $68 \cdot 9^{\mathrm{a}}$ & $68 \cdot 3^{a}$ & 0.88 & 0.05 \\
\hline \multicolumn{7}{|l|}{ Lys } \\
\hline Duodenum & 1.01 & 0.98 & 0.94 & 0.95 & 0.04 & 0.64 \\
\hline Ileum & 0.34 & 0.33 & 0.31 & 0.35 & 0.02 & 0.37 \\
\hline Reabsorption & 65.8 & 66.5 & $66 \cdot 7$ & $62 \cdot 6$ & 1.84 & 0.43 \\
\hline \multicolumn{7}{|l|}{ Phe } \\
\hline Duodenum & 0.65 & 0.91 & 0.82 & 0.83 & 0.05 & 0.07 \\
\hline Ileum & 0.24 & 0.29 & 0.30 & 0.27 & 0.02 & 0.30 \\
\hline Reabsorption & 63.5 & $68 \cdot 0$ & 63.5 & $67 \cdot 2$ & 1.60 & 0.18 \\
\hline \multicolumn{7}{|l|}{ Met } \\
\hline Duodenum & 0.07 & 0.06 & 0.08 & 0.07 & 0.01 & 0.24 \\
\hline Ileum & 0.03 & 0.02 & 0.03 & 0.03 & 0.01 & 0.16 \\
\hline Reabsorption & 63.1 & $65 \cdot 0$ & $65 \cdot 2$ & $64 \cdot 6$ & 2.39 & 0.92 \\
\hline \multicolumn{7}{|l|}{ Thr } \\
\hline Duodenum & 0.73 & 0.68 & 0.78 & 0.76 & 0.07 & 0.80 \\
\hline Ileum & 0.49 & 0.46 & 0.52 & 0.51 & 0.05 & 0.81 \\
\hline Reabsorption & 33.0 & $33 \cdot 1$ & 33.2 & 33.1 & 0.09 & 0.42 \\
\hline \multicolumn{7}{|l|}{ Val } \\
\hline Duodenum & 0.65 & 0.77 & 0.70 & 0.69 & 0.05 & 0.50 \\
\hline Ileum & 0.24 & 0.26 & 0.26 & 0.23 & 0.01 & 0.50 \\
\hline Reabsorption & 63.2 & $66 \cdot 7$ & $62 \cdot 3$ & $65 \cdot 8$ & 1.88 & 0.38 \\
\hline Ala & & & & & & \\
\hline Duodenum & 0.53 & 0.61 & 0.57 & 0.54 & 0.04 & 0.52 \\
\hline Ileum & $0 \cdot 19$ & 0.21 & 0.20 & 0.20 & 0.02 & 0.75 \\
\hline Reabsorption & $64 \cdot 8$ & $65 \cdot 6$ & $64 \cdot 3$ & $62 \cdot 8$ & $1 \cdot 29$ & 0.53 \\
\hline Gly & & & & & & \\
\hline Duodenum & $1 \cdot 17$ & $1 \cdot 10$ & $1 \cdot 13$ & 1.09 & 0.04 & 0.47 \\
\hline Ileum & 0.75 & 0.70 & 0.73 & 0.70 & 0.02 & 0.49 \\
\hline Reabsorption & 35.9 & $36 \cdot 1$ & $36 \cdot 0$ & $36 \cdot 1$ & 0.17 & 0.88 \\
\hline Tyr & & & & & & \\
\hline Duodenum & 0.39 & 0.37 & 0.36 & 0.43 & 0.02 & 0.18 \\
\hline Ileum & 0.14 & 0.12 & 0.14 & 0.15 & 0.01 & 0.26 \\
\hline Reabsorption & $64 \cdot 2$ & 68.4 & $61 \cdot 8$ & $64 \cdot 6$ & $2 \cdot 12$ & 0.27 \\
\hline Asp & & & & & & \\
\hline Duodenum & 1.07 & 1.30 & 1.20 & 1.08 & 0.05 & 0.07 \\
\hline Ileum & 0.67 & 0.81 & 0.76 & 0.68 & 0.03 & 0.06 \\
\hline Reabsorption & $37 \cdot 4$ & $37 \cdot 3$ & $37 \cdot 0$ & 37.5 & 0.12 & 0.10 \\
\hline Cys & & & & & & \\
\hline Duodenum & 0.01 & 0.02 & 0.02 & 0.02 & 0.01 & 0.35 \\
\hline Ileum & 0.01 & 0.01 & 0.01 & 0.01 & 0.01 & 0.39 \\
\hline Reabsorption & 64.7 & $65 \cdot 8$ & $67 \cdot 7$ & 65.4 & 1.29 & 0.48 \\
\hline Ser & & & & & & \\
\hline Duodenum & 0.71 & 0.70 & 0.64 & 0.70 & 0.06 & 0.82 \\
\hline Ileum & 0.24 & 0.23 & 0.23 & 0.26 & 0.02 & 0.62 \\
\hline Reabsorption & 65.9 & $66 \cdot 8$ & $64 \cdot 8$ & $62 \cdot 3$ & $2 \cdot 19$ & 0.54 \\
\hline Glu & & & & & & \\
\hline Duodenum & 0.76 & 0.76 & 0.72 & 0.77 & 0.03 & 0.62 \\
\hline Ileum & 0.47 & 0.47 & 0.45 & 0.44 & 0.02 & 0.73 \\
\hline Reabsorption & $38 \cdot 2$ & 38.0 & 38.0 & $42 \cdot 3$ & $1 \cdot 19$ & $0 \cdot 10$ \\
\hline
\end{tabular}

Table 3. Continued

\begin{tabular}{lccccccc}
\hline & \multicolumn{5}{c}{ Treatments } & & \\
\cline { 2 - 5 } Item & Maize & Wheat & Paddy & Sorghum & SEM & $P$ \\
\hline Total & & & & & & \\
$\quad$ Duodenum & 10.76 & 11.29 & 10.95 & 10.96 & 0.29 & 0.65 \\
$\quad$ Ileum & 4.87 & 4.95 & 4.94 & 4.99 & 0.10 & 0.86 \\
$\quad$ Reabsorption & 54.7 & 56.1 & 54.8 & 54.4 & 0.70 & 0.38 \\
\hline a,b Mean values within a row with unlike superscript letters were significantly \\
different $(P<0.05)$.
\end{tabular}

maintenance metabolisable energy ${ }^{(56)}$, and the level of feed intake also significantly influences the losses of EAA ${ }^{(31,54,55)}$.

\section{Ileal flows of endogenous nitrogen and endogenous amino acids}

The flow of endogenous protein at the terminal ileum balances between secretion and reabsorption. With ${ }^{15} \mathrm{~N}$ marker techniques, Larsen et al. ${ }^{(19)}$ found that the ileal proportion of water-soluble non-amino-N (NAN) of the total ileal NAN is similar to the proportion of the ileal EN in sheep ${ }^{(44,48,49)}$, supporting the assumption that endogenous protein in the ileum is located in the water-soluble phase. Zhou et al. ${ }^{(2)}$ reported that the average ileal flow of EN located in the water-soluble phase is $5 \cdot 0 \mathrm{~g} / \mathrm{kg}$ DMI in growing goats. In the present study, the average ileal flow of EN was $1.7 \mathrm{~g} / \mathrm{kg}$ DMI, with the differences potentially ascribed to different experimental diet compositions.

It was reported that about $70-80 \%$ of secreted endogenous protein is hydrolysed and reabsorbed before reaching the distal ileum ${ }^{(5758)}$. The major part of the remaining endogenous protein originates from deconjugated bile salts and mucin glycoprotein because these components are largely resistant to proteolysis and therefore escape reabsorption ${ }^{(59-61)}$. Glycine accounts for more than $90 \%$ of the total AA content of bile, and mucin glycoprotein is rich in Thr, Asp and Glu ${ }^{(62)}$. Gardner ${ }^{(63)}$ provided evidence for a substantial flux of Pro and Gly from the enterocytes into the intestinal lumen. It has also been reported that Thr, Asp and Glu are more slowly absorbed from the intestinal lumen than most other $\mathrm{AA}^{(59)}$. Therefore, endogenous protein usually has a high content of these $\mathrm{AA}^{(59,64)}$. The AA composition of endogenous protein in the present study is in agreement with this hypothesis.

Larsen et al. ${ }^{(19)}$ demonstrated that the small-intestinal reabsorption of EAA showed some extremes when the duodenal flows were estimated by the difference method, and pointed out that the reabsorption of EAA is related to the secretion of digestive juices with specific AA compositions. The average apparent reabsorption of EAA in the small intestine ranges from 62.3 to $82.5 \%$ in sheep ${ }^{(46,48)}$. The average apparent reabsorption of EAA was about $57.7 \%$, which was close to the lowest reported value in the present study. The significant differences of intestinal reabsorption of endogenous Leu need to be further studied.

\section{Conclusion}

In conclusion, the dietary starch sources did not significantly affect the duodenal and ileal losses of endogenous protein or the AA composition in growing goats. 


\section{Acknowledgements}

We acknowledge the participation of Z. T. for direction of the experimental design, Y. P. for assistance with analyses, S. L. for paper revision, S. T., Z. S. and X. H. for help with the fistulae surgery of goats, and M. W. for guidance with the animal experiments and laboratory analyses. C. Z. participated in the animal experiment, laboratory analysis, treatment of data and writing of the manuscipt.

We wish to express our appreciation to the Chinese Academy of Sciences (no. KSCX2-YW-N-022), the Ministry of Science and Technology of China (2008BADA7B04) and the Natural Science Foundation of Hunan Province (no. 05JJ10004) for providing the financial support for the present study.

There are no conflicts of interest in the present study.

\section{References}

1. Hess V, Ganier P, Thibault JN, et al. (2000) Comparison of the isotope dilution method for determination of the ileal endogenous amino acid losses with labelled diet and labelled pigs. Br J Nutr 83, 123-130.

2. Zhou CS, Jiang HL, Tan ZL, et al. (2008) Estimation of endogenous nitrogen and amino acids flow at the duodenum and ileum in growing goats fed on different NDF level diets. J Appl Anim Res 33, 137-144.

3. Larsen M, Madsen TG, Weisbjerg MR, et al. (2000) Endogenous amino acid flow in the duodenum of dairy cows. Acta Agric Scand 50, 161-173.

4. Misciattelli L (2001) Amino acid digestion and metabolism in the lactating dairy cow, p. 175. PhD Thesis, The Royal Veterinary and Agricultural University, Copenhagen.

5. National Research Council (2001) Protein and amino acids. In Nutrient Requirements of Dairy Cattle, 7th ed., pp. 43-104. Washington, DC: NRC.

6. Tamminga S, Schulze H, Van Bruchem J, et al. (1995) The nutritional significance of endogenous $\mathrm{N}$-losses along the gastro-intestinal tract of farm animals. Arch Tierernahr 48, 9-22.

7. Gabriel I, Lessire M, Juin H, et al. (2008) Variation in seed protein digestion of different pea (Pisum sativum L.) genotypes by cecectomized broiler chickens: 1 . Endogenous amino acid losses, true digestibility and in vitro hydrolysis of proteins. Livest Sci 113, 251-261.

8. Nyachoti CM, de Lange CFM, McBride BW, et al. (1997) Significance of endogenous gut protein losses in the nutrition of growing pigs. Can J Anim Sci 77, 149-163.

9. Zebrowska T \& Kowalczyk J (1991) Nitrogen secretion into isolated loops of the small intestine in conscious sheep. J Anim Physiol Anim Nutr 65, 133-139.

10. Huntington GB (1997) Starch utilization by ruminants: from basics to the bunk. J Anim Sci 75, 852-867.

11. Philippeau C, Le Deschault de Monredon F \& Michalet-Doreau B (1999) Relationship between ruminal starch degradation and the physical characteristics of corn grain. J Anim Sci 77, 238-243.

12. Swan CG, Bowman JGP, Martin JM, et al. (2006) Increased puroindoline levels slow ruminal digestion of wheat (Triticum aestivum L.) starch by cattle. J Anim Sci 84, 641-650.

13. Wang SP \& Tan ZL (2007) The effect of dietary starch sources on digestion and metabolism, meat quality, body anti-oxidation capability and activity of intestinal digestive enzymes in goats, pp. 103-104. PhD Thesis, Institute of Subtropical Agriculture, the Chinese Academy of Sciences.
14. Wang M, Jiang J, Tan ZL, et al. (2009) In situ ruminal crude protein and starch degradation of three classes of feedstuffs in goats. J Appl Anim Res 36, 23-28.

15. Lu DX \& Zhang PY (1996) Nutrition principles for goat. In Scientific Technology of Feeding Goat (publication in Chinese), pp. 71-126 [DX Lu and PY Zhang, editors]. Beijing: China Agriculture Press.

16. Tan ZL, Lu DX, Hu M, et al. (2001) Effects of dietary nitrogen sources on fiber digestion and ruminal fluid characteristics in sheep fed wheat straw. Asian-Aust J Anim Sci 14, 1374-1382.

17. Øskov ER \& McDonald I (1979) The estimation of protein degradability in the rumen from incubation measurements weighted according to rate of passage. J Agric Sci (Camb) 92, 499-503.

18. Reed JJ, Lardyl GP, Bauer ML, et al. (2004) Effect of field pea level on intake, digestion, microbial efficiency, ruminal fermentation and in situ disappearance in beef steers fed growing diets. J Anim Sci 82, 2123-2130.

19. Larsen M, Madsen TG, Weisbjerg MR, et al. (2001) Small intestinal digestibility of microbial and endogenous amino acids in dairy cows. J Anim Physiol Anim Nutr 85, 9-21.

20. AOAC (2002) Official Methods of Analysis, 16th ed. Washington, DC: AOAC.

21. Hansen B (1989) Determination of nitrogen as elementary N, an alternative to Kjeldahl. Acta Agric Scand 39, 113-118.

22. Mason VC, Bech-Andersen S \& Rudemo M (1980) Hydrolysate preparation for amino acid determinations in feed constituents. 8. Studies of oxidation conditions for streamlined procedures. Z Tierphysiol Tierernährg Futtermittelkd 43, 146-164.

23. Schurch AF, Lloyd LE \& Crampton EW (1950) The use of chromic oxide as an index for determining the digestibility of a diet. $J$ Nutr 41, 629-636.

24. Sun ZH, Tan ZL, Yao JH, et al. (2007) Effects of intra-duodenal provision of limiting amino acids on serum concentrations of immunoglobulins and tissue concentrations of DNA and RNA in growing goats fed a maize stover-based diet. Small Rumin Res 69, 159-166.

25. Hutton K, Bailey FJ \& Annison EF (1971) Measurement of the bacterial nitrogen entering the duodenum of ruminant using diaminopimelic acid as a marker. Br J Nutr 25, 165-173.

26. Dufva GS, Bartley EE, Arambel MJ, et al. (1982) Diaminopemelic acid content of feeds and rumen bacteria and its usefulness as a rumen bacterial marker. J Dairy Sci 65, 1754-1759.

27. Evans RA, Axford RF \& Offer NW (1975) A method for estimating the quantities of microbial and dietary proteins flowing in the duodenal digesta of ruminants. Proc Nutr Soc 34, $65 \mathrm{~A}-66 \mathrm{~A}$

28. Powell MJD (1964) An efficient method for finding the minimum of a function of several variables without calculating derivatives. Comput J 7, 155-162.

29. SAS Institute Inc. (1996) SAS User's Guide: Statistics, version 6, 12 ed. Cary, NC: SAS Institute Inc.

30. Furuya S \& Kaji Y (1992) The effects of feed intake and purified cellulose on the endogenous ileal amino acid flow in growing pigs. Br J Nutr 68, 463-472.

31. Butts CA, Moughan PJ, Smith WC, et al. (1993) The effect of food dry matter intake on the endogenous ileal amino acid extraction determined under peptide alimentation in the $50 \mathrm{~kg}$ liveweight pig. J Sci Food Agric 62, 235-243.

32. Ouellet DR, Demers M, Zuur G, et al. (2002) Effect of dietary fiber on endogenous nitrogen flows in lactating dairy cows. J Dairy Sci 85, 3013-3025.

33. Butts CA, Moughan PJ, Smith WC, et al. (1993) Endogenous lysine and other amino acid flows at the terminal ileum of the growing pig ( $20 \mathrm{~kg}$ body weight): the effect of protein-free, synthetic amino acid, peptide and protein alimentation. $J$ Sci Food Agric 61, 31-40. 
34. Barth CA, Lunding B, Schmitz M, et al. (1993) Soybean trypsin inhibitor(s) reduce absorption of exogenous and increase loss of endogenous protein in miniature pigs. $J$ Nutr 123, $2195-2220$

35. Schulze H (1994) Endogenous ileal nitrogen losses in pigs dietary factors. PhD Thesis, Wageningen Agricultural University

36. Jansman AJM, Enting H, Verstegen MWA, et al. (1995) Effects of hulls of faba beans (Vicia faba) with low or high content of condensed tannins on the apparent ileal and fecal digestibility of nutrients and the excretion of endogenous protein in ileal digesta and feces of pigs. J Anim Sci 73, 118-127.

37. Wheeler TB, Wangsness PJ, Muller LD, et al. (1980) Addition of sodium bicarbonate to complete pelleted diets fed to dairy calves. J Dairy Sci 63, 1855-1863.

38. Lesmeister KE, Tozer PR \& Heinrichs AJ (2004) Development and analysis of a rumen tissue sampling procedure. J Dairy $S c i$ 87, 1336-1344.

39. Coverdale JA, Tyler HD, Quigley JD, et al. (2004) Effects of various levels of forage and form of diet on rumen development and growth in calves. J Dairy Sci 87, 2554-2562.

40. Lohakare JD, Pattanaik AK \& Khan SA (2006) Effect of dietary protein levels in the performance, nutrient balance, metabolic profile and thyroid hormones of crossbred calves. Asian-Aust J Anim Sci 19, 1588-1596.

41. Khan MA, Lee HJ, Lee WS, et al. (2007) Starch source evaluation in calf starter: I. Feed consumption, body weight gain, structural growth, and blood metabolites in Holstein calves. J Dairy Sci 90, 5259-5268.

42. Theurer CB, Lozano O, Alio A, et al. (1999) Steam-processed corn and sorghum grain flaked at different densities alter ruminal, small-intestinal, and total tract digestibility of starch by steers. J Anim Sci 77, 2824-2831.

43. Owens FN, Secrist DS, Hill WJ, et al. (1998) Acidosis in cattle: a review. J Anim Sci 76, 275-286.

44. Hamilton TS, Mitchell HH \& Kick CH, et al. (1927-8) New Method Tested in Digestion Trials, 41st annual report, pp. 199-221. Champaign, IL: Illinois Agricultural Experimental Station.

45. Crampton EW \& Lloyd LE (1950) Studies with sheep on the use of chromic oxide as an index of digestibility of ruminant rations. $J$ Nutr 45, 319-327.

46. Lammers-Wienhoven SCW, Voigt J, Ram L, et al. (1997) Effect of cell wall, dry matter and protein supply on endogenous nitrogen flow in the small intestine of sheep. J Anim Physiol Anim Nutr 78, 129-140.

47. Hannah SM, Cochran RC, Vanzant ES, et al. (1991) Influence of protein supplementation on site and extent of digestion, forage intake, and nutrient flow characteristics in steers consuming dormant bluestem-range forage. J Anim Sci $\mathbf{6 9}$, $2624-2633$

48. Van Bruchem J, Voigt J, Lammers-Wienhoven SCW, et al. (1997) Secretion and re-absorption of endogenous protein along the small intestine of sheep: estimates derived from ${ }^{15} \mathrm{~N}$ dilution of plasma non-protein-N. Br J Nutr 77, 273-286.

49. Sandek A, Krawielitzki K, Kowalczyk J, et al. (2001) Studies on $\mathrm{N}$-metabolism in different gastrointestinal sections of sheep using the digesta exchange technique: 2 . Passage of endogenousnitrogen. J Anim Feed Sci 10, 605-618.

50. Lapierre H, Ouellet DR, Berthiaume R, et al. (2008) Distribution of ${ }^{15} \mathrm{~N}$ in amino acids during ${ }^{15} \mathrm{~N}$-leucine infusion: impact on the estimation of endogenous flows in dairy cows. J Dairy Sci 91, 2702-2714.

51. Jensen C, Weisbjerg MR \& Hvelplund T (2006) Evaluation of methods for estimating the amino acid supply to the duodenum of microbial, endogenous and undegraded feed protein on maize silage diets fed to dairy cows. Anim Feed Sci Technol 131, 1-24.

52. Moughan PJ, Souffrant WB \& Hodgkinson SM (1998) Physiological approaches to determining gut endogenous amino acid flows in the mammal. Arch Tierernähr 51, 237-252.

53. Hess V \& Sève B (1999) Effect of body weight and feed intake level on basal ileal endogenous losses in growing pigs. J Anim Sci 77, 3281-3288

54. Stein HH, Trottier NL, Bellaver C, et al. (1999) The effect of feeding level and physiological status on total flow and amino acid composition of endogenous protein at the distal ileum in swine. J Anim Sci 77, 1180-1187.

55. James KAC, Butts CA, Koolaard JP, et al. (2002) The effect of food dry matter intake on the flow of amino acids at the terminal ileum for rats fed an enzyme-hydrolysed casein-based diet. $J S_{c i}$ Food Agric 82, 1128-1135.

56. Moter V \& Stein HH (2004) Effect of feed intake on endogenous losses and amino acid and energy digestibility by growing pigs. J Anim Sci 82, 3518-3525.

57. Souffrant WB, Rérat A, Laplace JP, et al. (1993) Exogenous and endogenous contributions to nitrogen fluxes in the digestive tract of pigs fed a casein diet. III. Recycling of endogenous nitrogen. Reprod Nutr Dev 33, 373-382.

58. Krawielitzki K, Kreienbring F, Zebrowska T, et al. (1994) Estimation of $\mathrm{N}$ absorption, secretion, and re-absorption in different intestinal secretions of growing pigs using the ${ }^{15} \mathrm{~N}$ isotope dilution method. In Digestive Physiology in Pigs, vol. 1, EAAP publication no. 80, pp. 79-82 [WB Souffrant and H Hagemeister, editors]. Bad Doberan, Germany: EAAP.

59. Taverner MR, Hume ID \& Farrell DJ (1981) Availability to pigs of amino acids in cereal grains. 1. Endogenous levels of amino acids in ileal digesta and faeces of pigs given cereal diets. $\mathrm{Br} \mathrm{J}$ Nutr 46, 149-158.

60. Fuller MF \& Cadenhead A (1991) Effect of the amount and composition of the diet on galactosamine flow from the small intestine. EAAP publication no. 54, pp. 330-333 [MWA Verstegen, J Huisman and LA den Hartog, editors]. Wageningen, The Netherlands: Pudoc.

61. Moughan PJ \& Schuttert G (1991) Composition of nitrogencontaining fractions in digesta from the distal ileum of pigs fed a protein-free diet. $J$ Nutr 121, 1570-1574.

62. Souffrant WB (1991) Endogenous nitrogen losses during digestion in pigs. In Digestive Physiology in Pigs, EAAP publication no. 54, pp. 147-166 [MWA Verstegen, J Huisman and LA den Hartog, editors]. Wageningen, The Netherlands: Pudoc.

63. Gardner MLG (1975) Absorption of amino acids and peptides from a complex mixture in the isolated small intestine of the rat. J Physiol 52, 233-256.

64. Homes JH, Bayley HS \& Leadbeater PA (1974) Digestion of protein in small and large intestine of the pig. Br J Nutr 32, $479-489$

65. Zhang HF \& Zhang ZY (1998) Feed composition and nutrition values in china. In Animal Nutrition Parameters and Feeding Standard (publication in Chinese), pp. 22-92 [HF Zhang and ZY Zhang, editors]. Beijing: China Agriculture Press. 